\title{
Fate of infectious salmon anaemia virus (ISAV) in experimentally challenged blue mussels Mytilus edulis
}

\author{
Cecilie K. Skår, Stein Mortensen* \\ Institute of Marine Research, PO Box 1870, Nordnes, 5817 Bergen, Norway
}

\begin{abstract}
In order to investigate the potential role of blue mussels Mytilus edulis as a vector of the fish pathogenic infectious salmon anaemia virus (ISAV), we developed an experimental bioaccumulation system in which mussels can accumulate virus during normal filtration. Detection of virus in mussels was performed by means of real-time RT-PCR. ISAV-RNA was detected in the mussels until $72 \mathrm{~h}$ post-challenge. Hepatopancreas homogenate from experimentally challenged mussels was injected into salmon. All the fish injected with homogenate prepared immediately after accumulations were strongly ISAV positive $4 \mathrm{wk}$ post-challenge. In the group injected with homogenate prepared $24 \mathrm{~h}$ after the challenge, 1 fish out of 25 was weakly ISAV positive. All of the fish that were challenged with mussel homogenate prepared $96 \mathrm{~h}$ after accumulation were ISAV negative. Mussels sampled from a tank with experimentally infected salmon demonstrating clinical signs consistent with ISA (infectious salmon anaemia) and mussels collected on net pen cages during ISA outbreaks in Atlantic salmon were all ISAV negative. The results indicate that the ISAV is rapidly inactivated in mussels and that mussels are not a likely reservoir host or vector for ISAV.
\end{abstract}

KEY WORDS: Mussels $\cdot$ Mytilus edulis $\cdot$ Atlantic salmon $\cdot$ Salmo salar $\cdot$ Infectious salmon anaemia virus $\cdot$ ISAV $\cdot$ Uptake $\cdot$ Inactivation $\cdot$ Vectors

\section{INTRODUCTION}

An understanding of how pathogenic agents are transmitted is crucial in both aquaculture and natural resource management. In the process of establishing safe distances between aquaculture sites, models for the protection of wild fish and shellfish populations and models for sustainable polyculture, questions regarding the spread of disease are frequently raised. Diseases in wild or farmed populations usually lead to restrictions in the movement of fish, shellfish and other potentially contagious material. However, pathogenic agents may be spread via water masses, wild carriers, or vectors, and restrictions do not fully ensure the control of disease spread by these routes (Mortensen 2000, Mortensen et al. 2006). Water is both a dilution and transport medium, and the fate of pathogenic agents shed into the water is dependent upon a series of fac- tors, including dilution, inactivation by UV light, or other physical and chemical factors, particle bonding and uptake in filter-feeding organisms or particlefeeding plankton (Noble \& Fuhrman 1997, Sinton et al. 2002, Wilhelm et al. 2003).

If particle feeders such as bivalve molluscs trap the pathogenic agents, they may act as vectors or reservoirs. In most cases, such mechanisms of diffusion may be considered passive, as pathogenic agents are trapped, ingested and sometimes accumulated by the normal food uptake of the filter feeders. Viruses are not regarded as a natural feed for bivalves, but it has been shown that they may be efficiently trapped in the mucus strings during feeding (Di Girolamo et al. 1977). As reviewed by Lees (2000), work on the accumulation and spread of viruses concerns mainly agents that are pathogenic to humans, but there are also a few reports of detections of fish pathogenic agents (Meyers 1984, 
Mortensen et al. 1990, Starliper et al. 1998). In human pathology, disease normally breaks out when contagious shellfish are consumed. If the pathogenic agent is not inactivated when it passes through the gut of the vector, both faeces, pseudofaeces and mucus fragments may contain low levels of agents in a potentially infectious state. Such particles may be eaten and passed upwards to the next level in an aquatic food chain and, thus, may represent a risk of disease transmission.

In aquaculture, there is a particular focus on avoiding the spreading of non-eradicable diseases, where neither eradication, nor vaccination strategies can be successfully employed. A number of viral diseases have affected Norwegian fish farms. Infectious pancreatic necrosis (IPN), pancreas disease (PD) and infectious salmon anaemia (ISA) all have severe impacts on the aquaculture production of salmon, as have viral nervous necrosis (VNN) and IPN on halibut production (Bergh et al. 2001). Understanding the transmission and distribution of these pathogenic agents is important in the establishment of sustainable management aquaculture models and the protection of wild fish resources.

The blue mussel Mytilus edulis is widely distributed and present in large numbers in fish and shellfish farm installations. The persistence of pathogenic agents in these mussels could turn them into pathogen reservoirs, representing a risk of disease transmission and limiting the effect of fallow periods and eradication programmes. The aim of this study was to examine the uptake of the pathogenic infectious salmon anaemia virus (ISAV) in mussels and to investigate the potential transmission of ISAV from fish to mussels and vice versa.

\section{MATERIALS AND METHODS}

Virus. The virus used originated from disease outbreaks in Atlantic salmon Salmo salar and had previously been used in salmon challenge experiments. Expt 1 was performed using the ISAV isolate Glesvær/ 89, provided by Dr. Are Nylund. The other experiments were performed with ISAV isolate Bremnes/98, propagated and provided by Dr. K. E. Christie (Intervet Norbio, Bergen) (Glover et al. 2006).

Mussels. Mussels Mytilus edulis used in the experiments were collected from a wild population in Lindås, near Bergen, Norway, and kept in a storage seawater tank at the Institute of Marine Research until use. There are no fish farms in the vicinity of the collection site. Mussels were tested for the presence of ISAV before experiments by using real-time reverse transcriptase (RT)-PCR as described below. The mussels were observed twice daily and were not fed during the experimental period.

Salmon. Unvaccinated Atlantic salmon Salmo salar (mean weight $90 \mathrm{~g}$ ) reared at a commercial farm (Jakta Ltd, Osterøy, northeast of Bergen) were used in Expt 1. In Expt 3, salmon (mean weight $60 \mathrm{~g}$ ) reared at the Institute of Marine Research in Matre, Norway, were used. The fish were kept at approximately $9^{\circ} \mathrm{C}$ at a salinity of 34 and were fed daily with a commercial salmon feed.

Three challenge experiments were performed. There was a 2 yr time gap between Expt 1 and Expts 2 and 3. Available virus, virus propagation protocols and the supply of fish were therefore different in Expt 1 and in Expts 2 and 3.

Expt 1. Virus detection in mussels cohabitating with ISA-infected salmon. Before the start of the experiment, 4 fish and 5 mussels were tested for ISAV by real-time RT-PCR as described below. Salmon and mussels were then transferred to 2501 tanks. Both the challenged and the negative control group held 20 salmon and 400 mussels. Salmon were anaesthetised with benzocaine before injections. Fish in the challenged group were intraperitoneally injected with $0.2 \mathrm{ml}$ ISAV diluted to an approximate titre of $5 \log _{10}$ $\mathrm{TCID}_{50} \mathrm{ml}^{-1}$ in Eagle's minimum essential medium (EMEM) cell culture medium (Sigma M-2279). Fish in the negative control group were injected with $0.2 \mathrm{ml}$ EMEM cell culture medium without virus.

Three live fish and 10 mussels were sampled on Day 10 post-injection. Thereafter, only dead and moribund fish were removed. Mussels were sampled on Days 18, 28 and 35. Twenty mussels were sampled each time. From the negative control group, 20 mussels and 3 fish were sampled on Days 0, 11, 23, 31 and 38 , in order to ensure that ISAV was not introduced into the experimental system during the period of the experiments. Salmon kidney and mussel hepatopancreas tissues were processed and tested for ISAV by real-time RT-PCR.

Expt 2. ISAV uptake in mussels. In order to measure ISAV uptake in mussels, 3 bioaccumulation experiments were performed. In each, 60 mussels were placed in a $19 \mathrm{l}$ aquarium containing $5 \mathrm{l}$ of seawater in a temperature-controlled room at $7^{\circ} \mathrm{C}$. An air-lift pump circulated the water and provided aeration. Mussels were left to acclimate and start filtration for $4 \mathrm{~h}$. An ISAV suspension in L15 (Leibowitz) cell culture medium (Sigma L-5520) was then slowly added until the final virus concentration in the aquarium was $3.4 \log _{10} \mathrm{TCID}_{50} \mathrm{ml}^{-1}$. Mussels were left for $2 \mathrm{~h}$ to accumulate the virus, and were then removed. External shell surfaces were scrubbed and washed with Virkon (Antec International) $(1 \%)$, followed by running tap water. Ten mussels were immediately opened with a 
scalpel; pieces of hepatopancreas were dissected out, transferred to RNAlater (Ambion) and frozen at $-80^{\circ} \mathrm{C}$ until virus analysis. The rest of the mussels were transferred to an $80 \mathrm{l}$ tank with running seawater at $9^{\circ} \mathrm{C}$. Hepatopancreas samples were then dissected from 10 mussels on Days 1, 2, 3, 4 and 8 post-transfer as described above and analysed using real-time RT-PCR as described below.

Expt 3. Inoculation of salmon with tissue homogenate from ISAV-contaminated mussels. Thirty-four mussels were allowed to accumulate the ISAV as described above. Accumulation time was increased to $9 \mathrm{~h}$ in order to ensure that all mussels resumed normal filtration activity during the accumulation period. Ten mussels were then removed for the preparation of homogenate for the salmon challenge: hepatopancreas tissues were dissected out from each mussel. Small pieces were transferred to RNAlater (Ambion) and frozen at $-80^{\circ} \mathrm{C}$ until virus analysis. The rest of the tissues were pooled, weighed and homogenised using a Mixer Mill MM 300 (Retsch) and diluted 1:50 (w/v) in L15 medium. The homogenate was filtered through a sterile $0.22 \mu \mathrm{m}$ filter (Millipore) before challenge of the fish. Hepatopancreas from each mussel and the homogenate used in the challenge experiment were tested for ISAV using real-time RT-PCR. The remaining 24 mussels were transferred to an 801 tank with running seawater. New challenge samples from 10 mussels were prepared 24 and $96 \mathrm{~h}$ after transfer. Salmon (mean weight $60 \mathrm{~g}$ ) were kept in three $250 \mathrm{l}$ tanks, with 25 fish tank ${ }^{-1}$. Fish were anaesthetised with benzocaine and intraperitoneally injected with $0.2 \mathrm{ml}$ of mussel hepatopancreas homogenate that had been sampled either immediately, 24, or $96 \mathrm{~h}$ after ISAV accumulation by the mussels. Three control groups, each containing 10 salmon kept in 801 tanks, were included: (1) positive control, where salmon were injected with $0.2 \mathrm{ml}$ ISAV suspension at a concentration of $4.4 \log _{10} \mathrm{TCID}_{50} \mathrm{ml}^{-1}$; and (2) and (3) negative controls, where salmon were injected with $0.2 \mathrm{ml}$ tissue homogenate from non-challenged mussels. Fish were observed twice daily until the experiment was terminated after $34 \mathrm{~d}$. Dead and moribund fish were removed. Pieces of head kidney were collected from dead and moribund fish, as well as from the survivors, and tested for ISAV by real-time RT-PCR.

Extraction of total RNA and real-time RT-PCR. Total RNA was extracted from tissue using the RNeasy Mini isolation kit (Qiagen $\mathrm{GmbH}$ ) according to the manufacturer's recommendations for tissue samples. Total RNA was eluted from the matrix twice with $30 \mu \mathrm{l}$ of RNase-free water. Reverse transcription of the total RNA was carried out in a total volume of $15 \mu \mathrm{l}$ using


PCR Buffer II (Applied Biosystems), 18.75 U Moloney murine leukemia virus (M-MuLV reverse transcriptase (Applied Biosystems), $5.0 \mathrm{mM} \mathrm{MgCl} 2,500 \mu \mathrm{M}$ of each dNTPs and 6 U RNase inhibitor (Applied Biosystems). The mixture was incubated at $25^{\circ} \mathrm{C}$ for $10 \mathrm{~min}, 42^{\circ} \mathrm{C}$ for $30 \mathrm{~min}$ and $95^{\circ} \mathrm{C}$ for $5 \mathrm{~min}$.

The PCR reaction mixture (final volume: $25 \mu \mathrm{l}$ ) was prepared as follows: $1 \times$ TaqMan Universal PCR Master Mix (Applied Biosystems), $900 \mathrm{nM}$ of each of the 2 ISAV Segment 8-derived primers ISAV-SEG8S8_2F (5'-CGACGATGACTCTCTACTGTGTGAT-3') and ISAV-SEG8-S8_2R (5'-TCATCAGTGTCGCCATGCTT-3'), 250 nM TaqMan MGB probe (6-FAM-5'ACGGTGGATCTTTC-3') (Plarre et al. 2005) and $5 \mu \mathrm{l}$ cDNA were added. When testing salmon tissue, an internal control for detecting elongation factor alpha was also used in the PCR mixture, then $40 \mathrm{nM}$ each of the 2 primers EL.1A-ELAF (5'-CCCCTCCAGGACG TTTACAAA-3') and EL.1A-ELAR (5'-CACACGGCCCACAGGTACA-3') and $250 \mathrm{nM}$ TaqMan MGB probe (6-VIC-5' -ATCGGTGGTATTGGAAC-3') (Moore et al. 2005) were added to the PCR reaction mixture. Positive and negative controls were systematically included in each reverse transcription and PCR experiment. The reaction was run on an ABI-Prism Model 7700 under the following reaction conditions: $2 \mathrm{~min}$ at $50^{\circ} \mathrm{C}$, $10 \mathrm{~min}$ at $95^{\circ} \mathrm{C}$, followed by 40 cycles consisting of $15 \mathrm{~s}$ at $95^{\circ} \mathrm{C}$ and $1 \mathrm{~min}$ at $60^{\circ} \mathrm{C}$. Accumulated data were analysed using the computer program Sequence Detector Version 1.9 (Applied Biosystems).

\section{RESULTS}

\section{Expt 1. Virus detection in mussels cohabitating with ISA-infected salmon}

Salmo salar in the experimentally challenged group died 18 to 22 d post-challenge and revealed clinical signs of ISA, including darkening of the skin, accumulation of ascites in the abdomen, bleeding in the eyes and darkened liver. The 10 fish from the challenge group tested for ISAV with real-time RT-PCR were all positive. Mytilus edulis were actively filtrating during the experiment. No mussels died during the experimental period. All cohabitating mussels and all fish and mussels from the negative control groups were ISAV negative.

\section{Expt 2. ISAV-uptake in mussels}

Most mussels were observed actively filtrating during the experiment, but some specimens seemed to close their valves during the exposure and they stayed half-closed during the $2 \mathrm{~h}$ exposure period. After chal- 
lenge, 23 out of 30 were positive immediately after the accumulation. After 24 h, 1 out of 20 was positive, and, after 48 h, 3 out of 30 were positive. PCR detection of ISAV was observed in 1 of 20 mussels until $72 \mathrm{~h}$ postchallenge. No positive mussels were found at 4 or $8 \mathrm{~d}$ post-challenge (Fig. 1). No mussels died during the experimental period.

\section{Expt 3. Inoculation of salmon with tissue} homogenate from ISAV-contaminated mussels

Hepatopancreas samples from the 10 mussels and the homogenates used for injection immediately after challenge of the mussels were all positive for ISAV. The homogenate prepared from mussels $24 \mathrm{~h}$ after challenge with the virus was also positive for ISAV. Testing of single samples showed that 4 out of 10 mussels were positive. In the last group, where the homogenate was prepared from mussels $96 \mathrm{~h}$ postchallenge, 1 out of 10 mussels used was weakly positive. The homogenate, however, was negative.

Five salmon examined before the experiment were ISAV negative. Salmon in the negative control groups injected with mussel hepatopancreas homogenates survived the experimental period and were also ISAV negative. Salmon in the positive control group died in a classical ISA pattern. The first visible sign of infection in all fish was darkening of skin colour. The 10 fish in the positive control groups died in the period between 17 to $27 \mathrm{~d}$ post-challenge, and all revealed ascites in the abdomen, bleeding in the eyes and a darkened liver. All 10 dead fish were ISAV positive following testing with real-time RT-PCR.

In the batch of fish injected with mussel homogenate prepared immediately after the challenge of the mussels, 1 fish died $32 \mathrm{~d}$ post-injection. The remaining fish

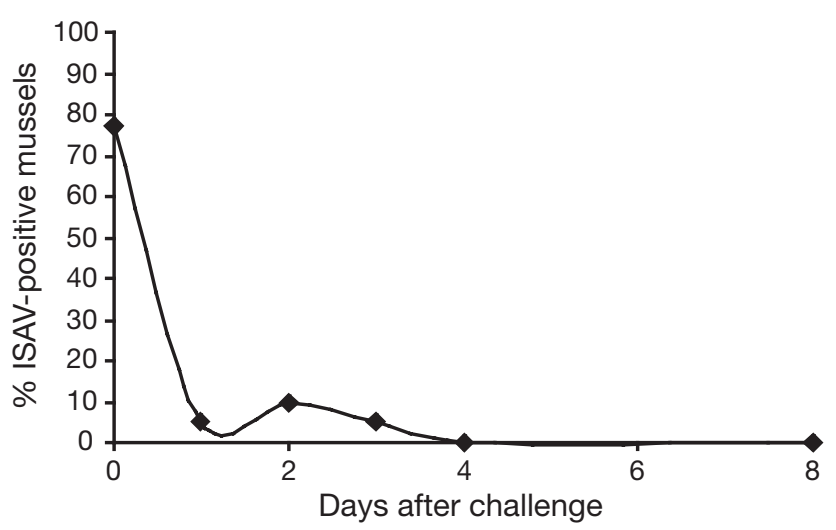

Fig. 1. Mytilus edulis. Percentage of infectious salmon anaemia virus (ISAV)-positive mussels immediately after a $2 \mathrm{~h}$ challenge, and at Days 2, 4 and 8 post-challenge
Table 1. Mytilus edulis and Salmo salar. Results from Expt 3, performed to test if infectious salmon anaemia virus (ISAV) in mussels was infectious after accumulation. Mussel hepatopancreas homogenates were injected into salmon 9, 24 and $96 \mathrm{~h}$ after accumulation in the mussels

\begin{tabular}{|lcc|}
\hline $\begin{array}{l}\text { Hours between } \\
\text { ISAV-challenge and } \\
\text { inoculation in salmon }\end{array}$ & $\begin{array}{c}\text { Number of } \\
\text { dead salmon }\end{array}$ & $\begin{array}{c}\text { Number of } \\
\text { ISAV-positive } \\
\text { salmon }\end{array}$ \\
\hline 9 & 1 & 19 \\
24 & 0 & 1 \\
96 & 0 & 0 \\
\hline
\end{tabular}

were alive when the experiment was terminated $34 \mathrm{~d}$ post-injection. However, 19 of the 25 fish examined for ISA virus with real-time RT-PCR were all strongly positive for the virus. In the fish group injected with homogenate prepared $24 \mathrm{~h}$ after the challenge of the mussels, 1 out of the 25 fish was weakly positive. All fish challenged with mussel homogenate prepared $96 \mathrm{~h}$ after accumulation were ISAV negative (Table 1).

\section{DISCUSSION}

The spreading potential of fish pathogenic viruses depends on their persistence both in seawater and in potential reservoir hosts or vectors. Some fish pathogenic viruses, like viral hemorrhagic septicaemia virus (VHSV), IPNV and nodaviruses retain their infectivity for periods of time long enough to enable spreading in natural seawater (Ahne 1982, Mortensen et al. 1998, Frerichs et al. 2000, Kocan et al. 2001). Detectable levels of ISAV particles are present in the water collected in farms holding salmon suffering from ISA (Løvdal \& Enger 2002). Passage to new hosts through the water depends largely on inactivation processes in the water, where the effect of temperature and UV-light has been considered particularly important (Noble \& Fuhrman 1997, Sinton et al. 2002, Wilhelm et al. 2003). Øye \& Rimstad (2001) found that ISAV was very sensitive to UV-radiation, and Løvdal \& Enger (2000) suggested that ISAV is unstable in seawater and undergoes a 10-fold decline after approximately $40 \mathrm{~h}$ in sterilised seawater.

Our bioaccumulation experiments showed that ISAV was rapidly taken up by the mussel Mytilus edulis and could be detected in the digestive gland shortly after uptake. The finding of virus-negative mussels immediately after exposure was probably a result of closure and cessation of filtration by some of the mussels. Increasing the exposure time in Expt 2 resulted in $100 \%$ positive mussels. After uptake, the virus seemed to gradually disappear from the digestive tissues of the mussels and was not detected in the digestive gland after $4 \mathrm{~d}$. 
Normal digestion processes may inactivate viral agents after uptake. Particles that are not digested may also be removed by motile haemocytes through a gradual depuration process and be shed back into the water. The fate of a microbe in bivalve tissues will thus be due to a balance between uptake rate, digestion and depuration. Some viruses are surprisingly inert and remain infectious for long periods of time, in water, sediments, particles and filter-feeding organisms. An example is IPNV, which could be recovered for long periods of time from digestive tissues of experimentally contaminated scallops (Mortensen et al. 1992). In such cases, the virus is probably sequestered in the digestive tissues. If a virus persists for a long period of time, we can expect a slow, long-term depuration process, with a possible release of virus (Mortensen et al. 1992, Mortensen 1993). ISAV is an enveloped virus (Dannevig et al. 1995, Falk et al. 1997) and, thus, is considered relatively vulnerable to inactivation. Results from the present challenge experiments indicate that ISAV is rapidly inactivated in the mussel Mytilus edulis.

A positive PCR reaction represents the presence of nucleic acid fragments. Thus, in general, PCR results may not distinguish between infectious and non-infectious virus particles. However, the real-time PCR technique was capable of showing whether we had an increase or a decrease in the virus. The results from our bioaccumulation trials were confirmed when inoculating salmon with diluted digestive homogenate from ISAV-contaminated mussels. It was only possible to transmit ISAV to the salmon Salmo salar by injection of mussel homogenate until $24 \mathrm{~h}$ after the mussels had started accumulating ISAV. This shows that the level of infectious ISAV quickly decreases in the mussels after virus uptake.

There is always a contrast between the situation in the field and laboratory experiments. While virus shed in the water column in a fish farm during an outbreak is diluted in the water current, laboratory challenges are normally performed with high doses of pathogens in closed or semi-closed systems. Samples from mussels collected from salmon net-pens during 2 ISA outbreaks, from Sogn and Trøndelag, respectively, were negative (data not shown). This is also in accordance with the results from ISAV diagnostics of mussels sampled during 5 ISA outbreaks in Trøndelag (H. Hellberg, Veterinary Institute, Bergen, pers. comm.). The combination of laboratory challenge and analyses of field samples in the present study enabled us to make a relatively realistic risk assessment based on our results. In Expt 1, salmon inoculated with ISAV died in a classical ISA pattern, although ISAV was not detected in cohabitating mussels kept on the bottom of the tank. Expt 1 presumably represents a 'worst case' situation in comparison with the spread of virus in a net-pen during an outbreak. Together with the negative results of the ISAV detections in the mussels sampled during ISA outbreaks, our results indicate that ISAV is absent or diluted to non-detectable levels in mussels that are filtering virus-contaminated water during ISA outbreaks. In conclusion, our experiments suggest that mussels are not a likely reservoir host or vector for ISAV.

Acknowledgements. This work was funded by the Fishery and Aquaculture Industry Research Fund. Thanks are due to K. Korsnes, B. Hjeltnes and F. Nilsen for their assistance in performing the experiments, to L. Harkestad and A. G. Eriksen for technical assistance, A. Duinker for providing the mussels, A. Nylund, I. Gabestad and K. E. Christie for providing virus isolates and technical advice, and C. E. Arnesen for an extremely rapid transport of 1 of the field samples.

\section{LITERATURE CITED}

Ahne W (1982) Comparative studies of the stability of four fish-pathogenic viruses (VHSV, PFR, SVCV, IPNV). Zentbl Vetmed Reihe B 29:457-476

Bergh Ø, Nilsen F, Samuelsen OB (2001) Diseases, prophylaxis and treatment of the Atlantic halibut Hippoglossus hippoglossus: a review. Dis Aquat Org 48:57-74

Dannevig BH, Falk K, Namork E (1995) Isolation of the causal virus of infectious salmon anaemia (ISA) in a long-term cell line from Atlantic salmon head kidney. J Gen Virol 76: 1353-1359

Di Girolamo R, Liston J, Matches J (1977) Ionic bonding, the mechanism of viral uptake by shellfish mucus. Appl Environ Microbiol 33:19-25

Falk K, Namork E, Rimstad E, Mjaaland S, Dannevig BH (1997) Characterization of infectious salmon anemia virus, an orthomyxo-like virus isolated from Atlantic salmon (Salmo salar L.). J Virol 71:9016-9023

Frerichs GN, Tweedie A, Starkey WG, Richards RH (2000) Temperature, $\mathrm{pH}$ and electrolyte sensitivity, and heat, UV and disinfectant inactivation of sea bass (Dicentrarchus labrax) neuropathy nodavirus. Aquaculture 185:13-24

Glover KA, Skår C, Christie KE, Glette J, Rudra H, Skaala Ø (2006) Size-dependent susceptibility to infectious salmon anemia virus (ISAV) in Atlantic salmon (Salmo salar L.) of farm, hybrid and wild parentage. Aquaculture 254:82-91

Kocan RM, Hershberger PK, Elder NE (2001) Survival of the North American strain of viral hemorrhagic septicemia virus (VHSV) in filtered seawater and seawater containing ovarian fluid, crude oil and serum-enriched culture medium. Dis Aquat Org 44:75-78

Lees D (2000) Viruses and bivalve shellfish. Int J Food Microbiol 59:81-116

Løvdal T, Enger $\varnothing$ (2002) Detection of infectious salmon anemia virus in sea water by nested RT-PCR. Dis Aquat Org 49:123-128

Meyers TR (1984) Marine bivalve mollusks as reservoirs of viral finfish pathogens: significance to marine and anadromous finfish aquaculture. Mar Fish Rev 46:14-17

Moore LJ, Somamoto T, Lie KK, Dijkstra JM, Hordvik I (2005) Characterisation of salmon and trout CD8alpha and CD8beta. Mol Immunol 42:1225-1234

Mortensen S (1993) Passage of infectious pancreatic necrosis virus (IPNV) through invertebrates in an aquatic foodchain. Dis Aquat Org 16:41-45 
Mortensen S (2000) Scallop introductions and transfers, from an animal health point of view. Aquac Int 8:123-138

Mortensen SH, Hjeltnes B, Rødseth O, Krogsrud J, Christie KE (1990) Infectious pancreatic necrosis virus, serotype N1 isolated from Norwegian turbot (Scopthalmus maximus), halibut (Hippoglossus hippoglossus) and scallops (Pecten maximus). Bull Eur Assoc Fish Pathol 10:42-43

Mortensen S, Bachere E, Legall G, Mialhe E (1992) Persistence of infectious pancreatic necrosis virus (IPNV) in scallops (Pecten maximus). Dis Aquat Org 12:221-227

Mortensen SH, Nilsen RK, Hjeltnes B (1998) Stability of an infectious pancreatic necrosis virus (IPNV) isolate stored under different laboratory conditions. Dis Aquat Org 33:67-71

Mortensen S, Korsnes K, Bergh O (2006) 'Eyes wide shut' —a critical view of aquaculture health management and risk factors in the 'real world'. Bull Eur Assoc Fish Pathol 26:1-5

Noble R, Fuhrman J (1997) Virus decay and its causes in coastal waters. Appl Environ Microbiol 63:77-83

Editorial responsibility: Jo-Ann Leong,

Kaneohe, Hawaii, USA
Øye AK, Rimstad E (2001) Inactivation of infectious salmon anaemia virus, viral haemorrhagic septicaemia virus and infectious pancreatic necrosis virus in water using UVC irradiation. Dis Aquat Org 48:1-5

Plarre H, Devold M, Snow M, Nylund A (2005) Prevalence of infectious salmon anaemia virus (ISAV) in wild salmonids in western Norway. Dis Aquat Org 66:71-79

Sinton L, Hall C, Lynch P, Davies-Colley R (2002) Sunlight inactivation of fecal indicator bacteria and bacteriophages from waste stabilization pond effluent in fresh and saline waters. Appl Environ Microbiol 68:1122-1131

Starliper CE, Villella R, Morrison P, Mathias J (1998) Studies on the bacterial flora of native freshwater bivalves from the Ohio River. Biomed Lett 58:85-95

Wilhelm S, Jeffrey W, Dean A, Meador J, Pakulski J, Mitchell D (2003) UV radiation induced DNA damage in marine viruses along a latitudinal gradient in the southeastern Pacific Ocean. Aquat Microb Ecol 31:1-8

Submitted: December 1, 2005; Accepted: December 13, 2006 Proofs received from author(s): February 6, 2007 